\title{
PENGARUH MUTILASI DAN ABLASI TERHADAP MOLTING KEPITING BAKAU (Scylla Serrata) SEBAGAI KEPITING LUNAK
}

\author{
Khairiah $^{1}$, Supriyono Eko Wardoyo ${ }^{2}$ dan Pasril Wahid ${ }^{3}$ \\ ${ }^{13)}$ Fakultas Pertanian Universitas Nusa Bangsa Bogor \\ ${ }^{2)}$ Fakultas MIPA Universitas Nusa Bangsa Bogor \\ Jl. K. H. Soleh Iskandar, Cimanggu, Tanah Sareal - Bogor 16166

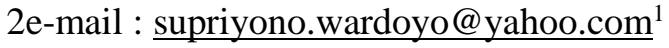

\begin{abstract}
Effect of Mutilation and Ablation to Molting of Mangrove Crab (Scylla serrata) as Soft Crab
\end{abstract}

\begin{abstract}
Soft crabs that are more expensive than regular crab, that having hard carapace, in nature and in culture are very difficult to find. This study aimed to get the soft crabs more easily controlled the number of molting in culture, by the method of mutilation and ablation. Thus the supply in market will be able to meet existing demand. Four treatment techniques had been implemented namely mutilation, ablation, ablation + mutilation, and controls which each performed four replications. Complete Randomized Desaign (CRD) was used because the experiment was conducted in a fairly homogeneous patch of tambak pond. Experimental unit in the form of bamboo pen cages with the size of $2 x 1 x 1 \mathrm{~m}$ filled with 20 crabs. All experimental crabs were ready for molting (dark color) even with 40-90 g of varied sizes. The results showed that each week until the third week, the average number of crabs per unit experiment with techniques of mutilation was always having highest of molting number, respectively 1.00, 3.25, and $11.00 \mathrm{crabs}$ and having the lowest mortality rate, respectively $0.25,1.75$, and 1.25 crabs, compared with the ablation, mutilations + ablation technique, and control. Statistically four treatments in molting, in week two and three was significantly different, eventhough in mortality was not $(\alpha=$ $5 \%$.
\end{abstract}

Keywords : mangrove crab (Scilla serrata), soft crabs, mutilation, ablation

\begin{abstract}
ABSTRAK
Kepiting lunak yang harganya lebih mahal dari kepiting biasa bercangkang keras, di alam maupun dalam budidaya sangat susah ditemukan. Penelitian ini bertujuan untuk mendapatkan kepiting lunak yang lebih mudah terkontrol jumlahnya dalam budidaya, dengan metoda mutilasi dan ablasi. Dengan demikian dalam pasar ketersediaannya akan dapat memenuhi permintaan yang ada. Empat perlakuan telah dilaksanakan yaitu teknik mutilasi, ablasi, mutilasi+ablasi, dan kontrol dengan masing-masing dilakukan empat kali ulangan. Rancangan Acak Lengkap (RAL) digunakan karena percobaan ini dilakukan di suatu petak tambak yang cukup homogen. Unit percobaan berupa keramba bambu tancap ukuran 2x1x1m yang diisi 20 kepiting yang semua kepiting dalam percobaan siap molting (warnanya gelap) meskipun dengan ukuran yang bervariatif 40-90 g. Hasil penelitian menunjukan bahwa tiap minggu sampai pada minggu ke tiga rata-rata jumlah kepiting per unit percobaan dengan teknik mutilasi selalu tertinggi terjadinya proses molting yaitu masing-masing 1,00; 3,25; dan 11,00 ekor dan mortalitasnya terendah yaitu 0,$25 ; 1,75$; dan 1,25 ekor dibanding dengan teknik ablasi, mutilasi+ablasi; dan kontrol. Secara statistik ke empat perlakuan dalam molting pada minggu ke dua dan ke tiga berbeda nyata hasil terbaik ditunjukkan oleh perlakuan mutilasi, meskipun dalam mortalitas tidak berbeda nyata (selang kepercayaan $95 \%)$.
\end{abstract}

Kata Kunci : Kepiting bakau (Scilla serrata), kepiting lunak, mutilasi, ablasi. 


\section{PENDAHULUAN}

Indonesia merupakan negara agraris, yaitu negara yang sebagian besar mata pencaharian penduduknya berasal dari sektor pertanian. Ruang lingkup pertanian sangat luas, mencakup pertanian, perikanan, peternakan, perkebunan dan kehutanan. Pertanian modern adalah pertanian yang selalu berubah sesuai dengan kebutuhan manusia. Baik dalam perubahan volume maupun jenis produksi. Penggunaan ilmu dan tehnologi yang berkembang, memungkinkan terciptanya jenis produk yang disesuaikan dengan apa yang dibutuhkan.

Kepiting produk perikanan merupakan salah satu sumber protein hewani yang dibutuhkan manusia untuk pertumbuhan dan memelihara kesehatannya. Mineral Selenium dalam kepiting berperan sebagai antioksidan dan untuk mencegah kerusakan sel dari radikal bebas penyebab kanker dan penyakit jantung.asak lemak omega-3 dalam kepiting berfungsi menurunkan kadar kolesterol jahat dalam darah sehingga mencegah penyakit kardiovaskuler (jantung) (Arriola, 1990).

Ketersediaan kepiting bakau (Scylla serrata) masih tergantung tangkapan dari alam. Untuk memenuhi permintaan pasar, petani tambak sudah membudidayakan kepiting disela - sela waktu luang mereka menunggu musim panen. Seiring berkembangnya teknologi makanan dan kemajuan ilmu pengetahuan konsumen cenderung lebih menyukai makanan yang instan dan siap saji. Dalam hal ini produk kepiting bakau cangkang keras sudah dirancang menjadi kepiting cangkang lunak (soft shelling crabs) sebagai makanan yang instan dan siap saji sesuai permintaan pasar. Konsumen lebih senang mengkonsumsi kepiting lunak. Karena susahnya mendapatkan kepiting lunuk di budidaya maupun di alam maka harga kepiting inipun relatif lebih mahal (Rp 80-85/kg) daripada kepiting cangkang keras (Rp 45-50/kg) (komunikasi pribadi dengan pengepul kepiting bakau di Desa Mayangan). Permintaan terhadap kepiting lunak tinggi, sementara persediaan terbatas. Di alam keberadaan kepiting lunak tidak dapat diprediksi dan susah didapat karena setelah molting kepiting bakau akan membenamkan diri atau bersembunyi di dalam lubang sampai cangkangya mengeras kembali (Pagcatipunan, 1972. Dalam Piliay, 1971).

Selama ini kepiting bakau biasa hanya dapat dikonsumsi sekian persen saja dari seluruh bagian tubuhnya. Bagian terbesar dari tubuh kepiting berupa limbah cangkang sebesar $60 \%$. Hanya sekitar $40 \%$ saja dari tubuhnya yang merupakan bagian yang bisa dimakan (edible portion) karena kepiting bakau memiliki cangkang yang keras (Hanafi dan Sulaeman, 1992). Untuk dapat memanfaatkan atau mengkonsumsi kepiting secara keseluruhan maka kepiting yang dikonsumsi harus dalam keadaan lunak yaitu yang baru molting (ganti kulit).

Pertumbuhan kepiting bakau sangat dipengaruhi oleh molting karena pertambahan bobot, panjang, dan lebar karapaks akan terjadi setelah molting. Selama masa pertumbuhan menjadi dewasa, kepiting akan mengalami pergantian kulit, antara 17-20 kali tergantung kondisi lingkungan dan pakan yang tersedia. Pada umumnya semua jenis hewan Crustacea (udang, kepiting) melakukan molting dalam pertumbuhan nya. Mulai dari fase larva sampai dewasa kepiting bakau akan mengalami secara terus - menerus proses ganti kulit. Pada saat ganti kulit tubuh kepiting bakau seluruhnya akan lunak. Selain itu untuk molting kepiting juga memerlukan kondisi lingkung an yang mendukung. Salinitas adalah salah satu faktor yang mempengaruhi proses molting pada kepiting bakau. Bahan organik secara alami juga dapat membantu proses molting pada kepiting. Kedalaman air tambak untuk molting dalam budidaya disarankan $70 \mathrm{~cm}$ ke atas, karena apabila kurang dari itu, akan menghambat kepiting untuk molting. Demikian juga lumut yang menutupi bagian badan kepiting lunak dapat menghambat proses molting yang pada akhirnya dapat menyebabkan kematiaan karena sifat dasar lumut yang mengikat (Arriola, 1990). 
Tehnik mutilasi dan ablasi diduga bisa mempercepat proses molting. Tapi seberapa berpengaruhnya kedua tehnik diatas masih membutuhkan penelitian ilmiah untuk mendukung apakah tehnik mutilasi atau ablasi yang lebih dominan dalam mempengaruhi terjadinya molting pada kepiting bakau.

\section{BAHAN DAN METODE PENELITIAN}

Penelitan dilaksanakan selama kurang lebih 2 (dua) bulan mulai 1 Maret 2011 sampai 1 April 2011 di tambak air payau (lampiran 1) desa Mayangan, Kec. Legonkulon, Kab. Subang, Jawa Barat. Pengamatan molting dan mortalitas dilaksanakan di lokasi penelitian setiap minggu sampai mingu ke 6. Pengukuran suhu dan $\mathrm{pH}$ air dilakukan di lapangan, sedangkan pengukuran salinitas air tambak dilakukan di Laboratorium Lingkungan Perairan IPB, Bogor.

Kepiting bakau (Scylla serrata) yang digunakan berasal dari perairan pantai desa Mayangan, Subang, Jawa Barat semua kepiting berwarna gelap indikator ciri - ciri molting. Berat awal kepiting yang dipakai berkisar antara 40 - 90 gram, panjang antara $37-43 \mathrm{~mm}$, dan lebar antara $53-64$. Penebaran kepiting bakau dilakukan dengan menempatkan dalam keramba tancap bilah bambu (dongdang) dengan ukuran 1 x 2 x 1 meter yang ditempatkan dalam tambak dengan kedalaman 1 meter. Kepadatan kepiting dalam dongdang adalah 20 ekor, penempatan perlakuan dalam keramba dilakukan yaitu mutilasi, ablasi, mutilasi+ablasi, dan kontrol. Semua perlakuan di ulang 4 kali (Lampiran 2).

Peralatan yang digunakan adalah thermometer untuk mengukur suhu air tambak, $\mathrm{pH}$ meter untuk mengukur $\mathrm{pH}$ air tambak, dan salinometer untuk mengukur salinitas air tambak. Peralatan dan perlengkapan lain yang digunakan adalah keranjang, ember dan golok untuk mencacah pakan wideng (kepiting batu) sebagai pakan. Pemberian pakan diberikan dengan frekuensi $2 \mathrm{kali} / \mathrm{hari}$ yaitu pagi jam 6 : 00 dan sore jam 16 : 00. Arriola (1990), menyatakan bahwa kepiting bakau adalah pemakan sesama jenis (cannibalisme) dan pemakan segala, misal pemakan algae, bangkai, sisa-sisa potongan kayu, bambu dan benda-benda lain yang membusuk. Waktu makan kepiting bakau tidak teratur tapi umumnya lebih aktif pada malam hari dari pada siang hari, sehingga kepiting tergolong hewan nokturnal yang aktif dimalam hari (Queensland Departement of Aparimary Industries, 1989). Pengukuran suhu air dilakukan setiap hari yaitu pagi jam 6:00, siang jam 13:00, dan sore jam 17:00. $\mathrm{pH}$ dan salinitas diukur seminggu sekali yaitu setiap hari senin dengan tiga titik sample air yang diambil pada waktu pagi hari. Jumlah kepiting molting diamati setiap hari mulai dari penebaran benih. Sedangkan SR dihitung setiap minggu masing - masing keramba.

\section{a. Mutilasi}

Bagi kepiting proses dari mutilasi merupakan proses alami yaitu usaha menghindari bahaya dan regeneratif dengan merangsang fisiologi hormonal untuk menumbuhkan kembali anggota badan yang patah atau rusak pada proses mutilasi diri sendiri. Naluri mutilasi diri sendiri dan menumbuhkan anggota tubuh yang patah (body building) ini juga ada pada cecak (tetapi cecak tidak melakukan molting untuk menumbuhkan anggota tubuhnya (Arriola, 1990).

Perlakuan mutilasi adalah secara sengaja mematahkan satu pasang capit dan tiga pasang kaki jalan. Secara alami kepiting akan melepaskan sendiri keempat pasang organ kakinya hanya dengan cara diganggu - ganggu saja dengan usaha menghindar dari bahaya yang datang, seperti halnya cecak. Secara sengaja satu paang kaki renang tidak di ganggu sehinga kepiting masih bisa berenang mencari makan agar tetap hidup sampai molting terjadi.

Prosedur tahapan proses mutilasi adalah sebagai berikut :

1. Siapkan hewan uji berupa kepiting bakau ukuran bobot antara 40-90 gram (13-14 ekor/kg) sebanyak 80 ekor (Lampiran 3) 
2. Lepaskan tali pengikat hewan uji

3. Timbang bobot individu hewan uji dan ukur panjang dan lebar karapaksnya/cangkang

4. Lepaskan satu pasang capit dan 3 pasang kaki hewan uji, serta sisakan satu pasang kaki renang

5. Masukkan kepiting yang telah dimutilasi kedalam media air yang mengandung anti septik MB (Methylen Blue) (Lampiran 6) dengan dosis 5 ppm selama 5 menit

6. Pindahkan kepiting yang telah dimutilasi kedalam tempat pemeliharaaan (karamba)

7. Pelihara dan amati kepiting yang telah dimutilasi sampai semua kepiting yang diberi perlakuan tersebut molting (ganti kulit)

8. Selama pemeliharaan kepiting diberi makan berupa wideng (kepiting batu) secara ad libitum (sekenyangkenyangnya)

9. Pengamatan meliputi kecepatan molting mencapai puncaknya, jumlah molting, jumlah mortalitas dalam satu karamba

10. Seluruh data percobaan dikumpulkan dan di catat dalam tabel data pengamatan.

\section{b. Ablasi}

Ablasi (memotong tangkai mata) akan menghambat kerja organ $-\mathrm{x}$ yang ada pada tangkai mata kepiting yang memproduksi berbagai hormon, diantaranya adalah MIH (Molting Inhibitor Hormon) yaitu hormon penghambat molting pada kepiting (Hanafi dan Sulaeman, 1992). Dengan membuang organ-x ini maka MIH tidak diproduksi sehingga proses molting akan lebih cepat terjadi. Sisa satu matanya kepiting bisa mencari dan melihat makanan supaya kepiting bisa bertahan hidup.

1. Persiapan hewan uji yaitu kepiting bakau ukuran 13 - 14 ekor/kg sebanyak 80 ekor

2. Hewan uji ditimbang untuk diukur bobot, panjang dan lebar.
3. Pemotongan tangkai mata $\pm 60 \%$ dari keseluruhan organ mata

4. Tali yang dipakai untuk mengikat hewan uji dibuka.

5. Setelah ablasi hewan uji dimasukkan dalam antiseptik (Methylen Blue) selama 5 menit

6. Setelah perendaman dalam methylen blue hewan uji dipelihara dalam karamba untuk diamati.

7. Pemberian pakan selama menunggu proses ganti kulit sangat diperlukan, yang diberikan adalah wideng secara ad libitum

8. Pengamatan meliputi kecepatan molting sampai jumlah puncaknya, jumlah molting, jumlah mortalitasnya dalam satu keramba

9. Seluruh data percobaan dikumpulkan dan di catat dalam tabel data pengamatan.

\section{c. Mutilasi dan Ablasi}

Mutilasi dan ablasi adalah kedua proses dilakukan pada satu kepiting.

1. Persiapan hewan uji yaitu kepiting bakau ukuran 13 - 14 ekor/kg sebanyak 80 ekor

2. Hewan uji ditimbang untuk diukur bobot, panjang dan lebar.

3. Tali yang dipakai untuk mengikat hewan uji dibuka

4. Kaki dicopot satu persatu yang dimulai dari satu pasang capit, 3 pasang kaki jalan.

5. Pemotongan tangkai mata $\pm 60 \%$ dari keseluruhan organ mata

6. Setelah ablasi dan mutilasi hewan uji dimasukkan dalam antiseptik MB (Methylen Blue) selama 5 menit

7. Setelah perendaman dalam methylen blue hewan uji dipelihara dalam dongdang ukuran $1 \mathrm{~m} \times 2 \mathrm{~m} \times 1 \mathrm{~m}$ untuk diamati.

8. Pengamatan meliputi kecepatan molting sampai jumlah puncaknya, jumlah molting, jumlah mortalitas dalam satu keramba

9. Seluruh data percobaan dikumpulkan dan di catat dalam tabel data pengamatan 


\section{d. Parameter Yang Diamati}

1. Kelangsungan Hidup, diamati setiap hari dan dihitung setiap minggu

2. $\quad$ Tingkat Molting

a. Kecepatan molting, diamati setiap hari dan dihitung setiap minggu

$b$. Jumlah molting, diamati setiap hari dan dihitung setiap minggu

c. Regenerasi organ tubuh setelah mutilasi (dan/atau ablasi)

3. Kualitas Air

a. Suhu, diukur 3X sehari selama percobaan

b. $\mathrm{pH}$, diukur $1 \mathrm{X}$ seminggu selama percoban

c. Salinitas, diukur $1 \mathrm{X}$ seminggu selama percobaan

\section{e. Analisis Statistik}

Data yang diperoleh dianalisis dengan uji $\mathrm{F}$, apabila uji $\mathrm{F}$ menunjukkan adanya pengaruh nyata dari perlakuan, maka dilakukan uji Duncan pada selang kepercayaan $95 \%$. Pengolahan data dilakukan dengan menggunakan software SAS. Uji stasistik dilakukan untuk menguji kesimpulan dari pengaruh taraf perlakuan yang diperoleh, di mana kita dihadapkan pada proses atau usaha untuk melakukan penolakan atau penerimaan terhadap hipotesis yang telah dibuat (Stell and Torie, 1987)

\section{HASIL DAN PEMBAHASAN}

\section{Molting}

Secara umum keempat perlakuan memberikan pengaruh, secara bertahap terjadi kenaikan dari rata - rata jumlah moltingnya per keramba/minggu, sampai pada puncaknya dan akhirnya menurun sampai pada titik nol pada pengamatan sampai ke 6 minggu (M6).Tehnik mutilasi selalu tertingi terjadinya proses molting yaitu masing - masing $1.00,3.25$, dan 11.00. Perlakuan mutilasi dan ablasi menunjukkan kecepatan molting pertama yang sama yaitu pada minggu pertama (M1) mekipun pencapaian puncak jumlah molting peralakuan mutilasi 11.0 dicapai paling cepat pada minggu ketiga (M3). Perlakuan mutilasi+ablasi dan kontrol, baik molting pertama serta pencapaian puncak, jauh paling ketinggalan masingmasing pada minggu keempat (M4) dan minggu kelima (M5). Jumlah rata - rata molting per keramba, perlakuan mutilasi memberikan angka yang paling tinggi (11.0). Disimpulkan perlakuan mutilasi yang pling efektif dalam hal jumlah molting dan kecepatan pencapaian puncak (Tabel 1).

\section{Mortalitas}

Demikian pula dengan data rata rata jumlah mortalitas per minggu/keramba menunjukkan trend yang sama seperti data molting. Tehnik mutilasi selalu terendah terjadinya proses mortalitas yaitu masing masing $0.25,1.75$, dan 1.25. Disimpulkan hal yang sama perlakuan mutilasi yang paling efektif dalam hal jumlah mortalitas dan keterlambatan pencapaian puncak (Tabel 2).

Satu hal perlu di laporkan mengapa justru yang kontrol (tanpa perlakuan) di dapatkan mortalitas yang tinggi, karena sempurnanya organ maka sifat kanibalisme dari kepiting itu sendiri tinggi (Tabel 2 dan Lampiran 5), selebihnya mortalitas di perlakuan mutilasi + ablasi juga tingi karena efek stres akibat ketidak sempurnaannya organ yang terlalu tinggi dari perlakuan mutilasi+ablasi tersebut.

\section{Regenerasi Organ Tubuh (kepiting yang di mutilasi)}

Regenerasi organ tubuh kepiting bakau yang di mutilasi berkembang dari hari ke hari (Lampiran 4) kakinya yang melipat secara alami di bungkus oleh selaput tipis (Lampiran 7). Setelah kaki tumbuh sempurna baru yang di bungkus oleh selaput tipis. Setelah cangkang lepas pada saat molting dan selaput lepas bersama cangkang. Setelah perkembangan organ kaki yang di mutilasi sudah 
sempurna ada maka kepiting akan melakukan proses molting (Lampiran 8). Kelengkapan organ kaki terjadi setelah molting (Lampiran 9), dimana setelah organ kaki kepiting lengkap lalu mengalami pengerasan cangkang dan kepiting kembali normal selama $6-7$ hari. Penambahan ukuran yang meliputi berat badan, lebar dan panjang cangkang kepiting, juga terjadi setelah proses molting. Hal ini sesuai dengan sifat dari hewan krustasea yang mengalami pertumbuhan dengan cara ganti kulit (molting), dimana pertambahan ukuran tubuh baru akan kelihatan setelah proses molting selesai. Pertambahan berat badan bisa terlihat dari jumlah individu kepiting per $\mathrm{kg}$, pada saat awal penelitian berjumlah 13 - 14 ekor $/ \mathrm{kg}$ kemudian disaat melakukan penimbangan pada akhir penelitian setelah kepiting molting bisa mencapai $8-10$ ekor/kg, dengan berat rata-rata setelah molting berkisar antara 98-122 gram, panjang antara $40-52 \mathrm{~mm}$, dan lebar berkisar antara $62-76 \mathrm{~mm}$.

Tabel 1. Tingkat molting Kepiting Bakau (Scylla serrata) pada semua Perlakuan (rata - rata Jumlah molting/jumlah Kepiting dalam Dongdang (20 ekor) Setiap Minggu).

\begin{tabular}{cccccccc}
\hline \multirow{2}{*}{ No } & \multirow{2}{*}{ Perlakuan } & \multicolumn{5}{c}{ Waktu (minggu) } \\
\cline { 3 - 7 } 1 & Mutilasi & $1 \mathrm{a}$ & $3.25 \mathrm{a}$ & $11.0 \mathrm{a}$ & $1.50 \mathrm{c}$ & $0.00 \mathrm{c}$ & $0.00 \mathrm{a}$ \\
\hline 2 & Ablasi & $0.5 \mathrm{a}$ & $1.75 \mathrm{~b}$ & $4.25 \mathrm{~b}$ & $6.50 \mathrm{a}$ & $0.25 \mathrm{c}$ & $0.00 \mathrm{a}$ \\
\hline 3 & Mutilasi+ablasi & $0.00 \mathrm{a}$ & $0.00 \mathrm{~b}$ & $2.25 \mathrm{c}$ & $5,25 \mathrm{ba}$ & $2.75 \mathrm{~b}$ & $0.00 \mathrm{a}$ \\
\hline 4 & Kontrol & $0.00 \mathrm{a}$ & $0.00 \mathrm{~b}$ & $0.00 \mathrm{~d}$ & $2.50 \mathrm{bc}$ & $6.25 \mathrm{c}$ & $0.25 \mathrm{a}$
\end{tabular}

Keterangan : Angka - angka yang diikuti dengan huruf yang sama arah vertikal tidak berbeda nyata menurut uji Duncan $5 \mathrm{M}$ : minggu.

Tabel 2. Tingkat Mortalitas Kepiting Bakau (Scylla serrata) pada semua Perlakuan (rata rata Jumlah Mortalitas/jumlah Kepiting dalam Dongdang (20 ekor) Setiap Minggu).

\begin{tabular}{cccccccc}
\hline & & \multicolumn{7}{c}{ Waktu (minggu) } \\
\cline { 3 - 7 } No & Perlakuan & M1 & M2 & M3 & M4 & M5 & M6 \\
\hline 1 & Mutilasi & $0.25 \mathrm{~b}$ & $1.75 \mathrm{a}$ & $1.25 \mathrm{a}$ & $0.00 \mathrm{~b}$ & $0.00 \mathrm{a}$ & $0 \mathrm{a}$ \\
\hline 2 & Ablasi & $1.25 \mathrm{~b}$ & $3.25 \mathrm{a}$ & $2.00 \mathrm{a}$ & $0.25 \mathrm{~b}$ & $0.00 \mathrm{a}$ & $0 \mathrm{a}$ \\
\hline 3 & Mutilasi+ ablasi & $4.00 \mathrm{a}$ & $2.25 \mathrm{a}$ & $1.25 \mathrm{a}$ & $2.00 \mathrm{a}$ & $0.25 \mathrm{a}$ & $0 \mathrm{a}$ \\
\hline 4 & Kontrol & $3.25 \mathrm{a}$ & $4.00 \mathrm{a}$ & $2.25 \mathrm{a}$ & $1.50 \mathrm{a}$ & $0.00 \mathrm{a}$ & $\mathrm{a}$ \\
\hline
\end{tabular}

Keterangan : Angka - angka yang diikuti dengan huruf yang sama arah vertikal tidak berbeda nyata menurut uji Duncan $5 \%$. M : minggu. 
Tabel 3. Rata - rata Suhu Air Selama Penelitian

\begin{tabular}{cccc}
\hline Waktu & $\begin{array}{c}\text { Kisaran suhu }\left({ }^{\circ} \mathbf{C}\right) \\
\text { selama masa percobaan }\end{array}$ & $\begin{array}{c}\text { Rata -rata } \\
\left({ }^{\circ} \mathrm{C}\right)\end{array}$ & Data referensi \\
\cline { 1 - 2 } Pagi $(6: 00-7: 00)$ & $25,2-28,7$ & 26,9 & \\
\cline { 1 - 2 } Siang $(13: 00-14: 00)$ & $26,8-31,3$ & 29,5 & $\begin{array}{c}23,0{ }^{\circ} \mathrm{C}-32,0{ }^{\circ} \mathrm{C} \\
(\text { Kasry, } 1991)\end{array}$ \\
\cline { 1 - 2 } Sore $(17: 00-17: 30)$ & $26,6-30,2$ & 28,4 & \\
\hline \multicolumn{2}{c}{ Rata - rata suhu harian } & 28,6 & \\
\hline
\end{tabular}

\section{d. Kualitas Air}

\section{2. $\mathrm{pH}$}

Dari hasil pengukuran $\mathrm{pH}$ setiap minggu selama penelitian (sebanyak lima kali) dilakukan setiap hari senin maka diperoleh kisaran $\mathrm{pH}$ antara $6,2-7,1$ nilai $\mathrm{pH}$ rata - rata 6,7. Nilai ini masih berada dalam batas kisaran toleransi untuk kehidupan kepiting bakau yang berkisar antara $6.5-7.5$ (Kasry, 1991).

\section{Salinitas}

Hasil pengukuran salinitas selama penelitian yang dilakukan lima kali maka diperoleh rata - rata nilai salinitas di lokasi penelitian adalah 31,2 - 33,6 ppt nilai salinitas rata - rata 32,4 ppt. Angka ini masih berada dalam kisaran toleransi nilai salinitas untuk kehidupan kepiting bakau yang berkisar antara $2 \mathrm{ppt}-50 \mathrm{ppt}$ (Queensland Departement of Primary Industries, 1989)

\section{e. Analisis Statistik}

Secara statistik dengan selang kepercayan $95 \%$ ke empat perlakuan dalam molting pada minggu ke dua dan ke tiga berbeda nyata meskipun dalam tingkat mortalitas tidak terdapat perbedaan yang nyata. Uji Duncan menunjukkan perlakuan
1. Suhu

mutilasi berbeda nyata dengan perlakuan perlakuan lain (Tabel 1 dan 2).

\section{KESIMPULAN DAN SARAN}

\section{KESIMPULAN}

1. Perlakuan mutilasi memberikan hasil molting yang paling tinggi dibandingkan dengan perlakuan perlakun lain serta hasil jumlah mortalitas paling rendah. Sehingga selanjutnya tehnik mutilasi paling baik untuk budidaya kepiting lunak.

2. Secara statistik ke empat perlakuan dalam molting pada minggu ke dua dan ke tiga berbeda nyata meskipun dalam mortalitas tidak pada selang kepercayan $95 \%$.

3. Kimia fisika air (suhu, $\mathrm{pH}$, dan salinitas) yang ada di tambak air payau desa Mayangan masih berada dalam kisaran layak untuk budidaya kepiting bakau.

\section{SARAN}

1. Saran perlu ada suatu percobaan mengenai kepiting yang menempatkan satu kepiting dalam satu ruangan karena sifat kanibalisme. 
2. Juga perlu saran suatu percobaan molting dengan perlakuan jenis makanan.

\section{DAFTAR PUSTAKA}

Arriola, F. J. 1990. A Preliminary Study of Life History of Scylla serrata Forskal. Phil. J. Sci. 73(4); 437-456. (http://sokafarm.blogspot.com/2009/2/budi daya-perikanan-dengankendalanya.html) (http://akuakulturunhas.blogsp ot.com./2009/03/kepitinglunakbehttp://)

Hanafi, A. dan Sulaeman. 1992. Teknologi Kepiting Bakau. (Scylla Serrata) dan pasca panen. Makalah disampaikan pada seminar sehari Prospek pengembangan dan Pemasaran kepiting Bakau sebagai
Komoditas Ekspor Non Migas. Ujung Pandang. 21 April 1992.

Kasry, A., 1991. Budidaya Kepiting Bakau dan Biologi Ringkas. Penerbit Bhratara, Jakarta.

Piliay, T. K. R. 1971, ed. Coastal Aquaculture in the Indo-Pasifik Region. Fishing News (Books) $362-365$.

Queensland Departement of Prmary Industries. 1989. Life Cycle of The Mud Crab (Scyllaserrata). Queensland Departement of Pirmary Industries. QL 84002. $2 \mathrm{p}$.

Steel, R. G. D., and J. H., Torrie, 1987, Principles and Prosedures of Statistiks, Mac Graw Hiu Book $C d$. Inc, New York. 


\section{LAMPIRAN}

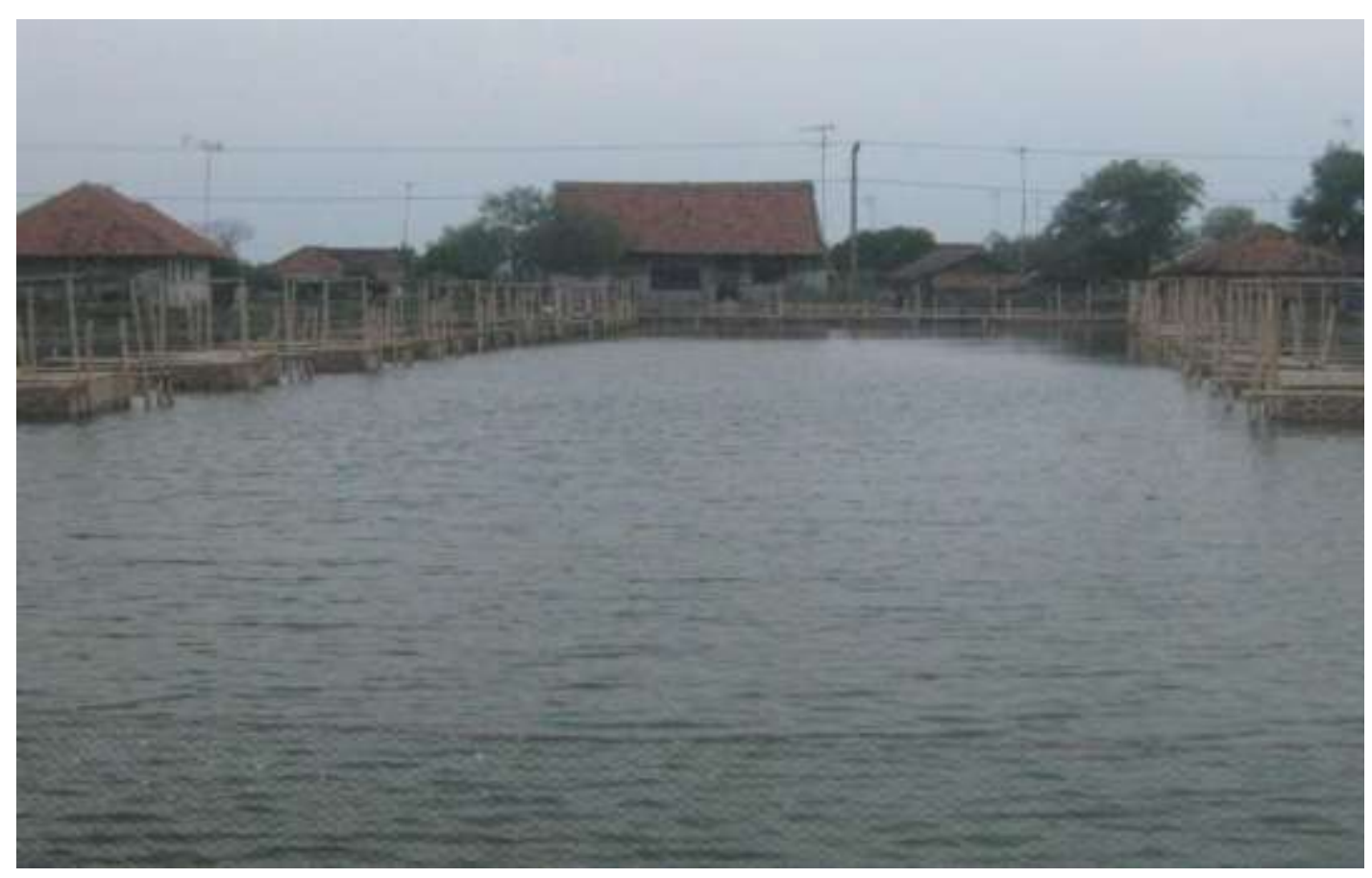

Lampiran1. Lokasi Penelitian

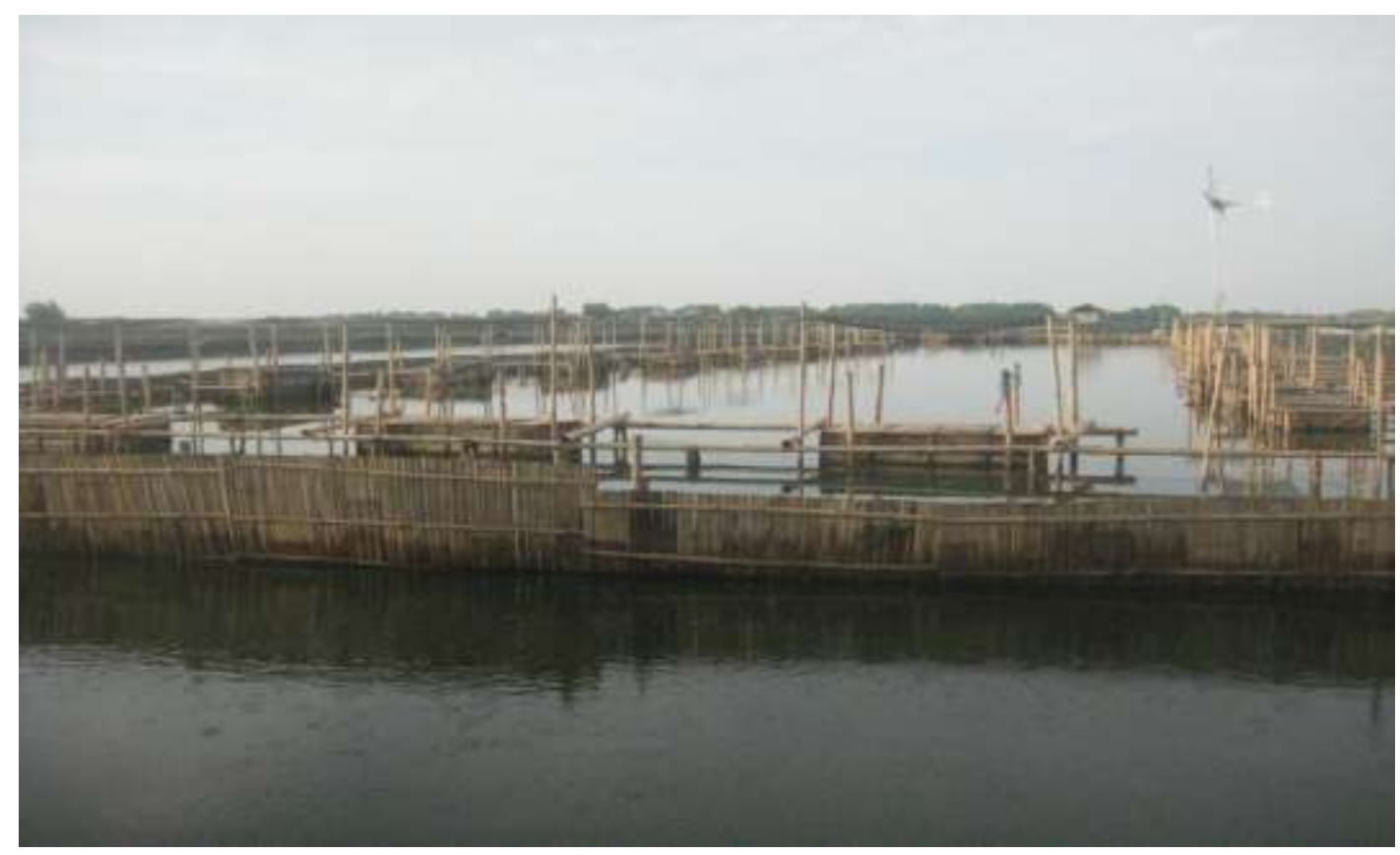

Lampiran 2. Penempatan Hewan Uji dalam Keramba 


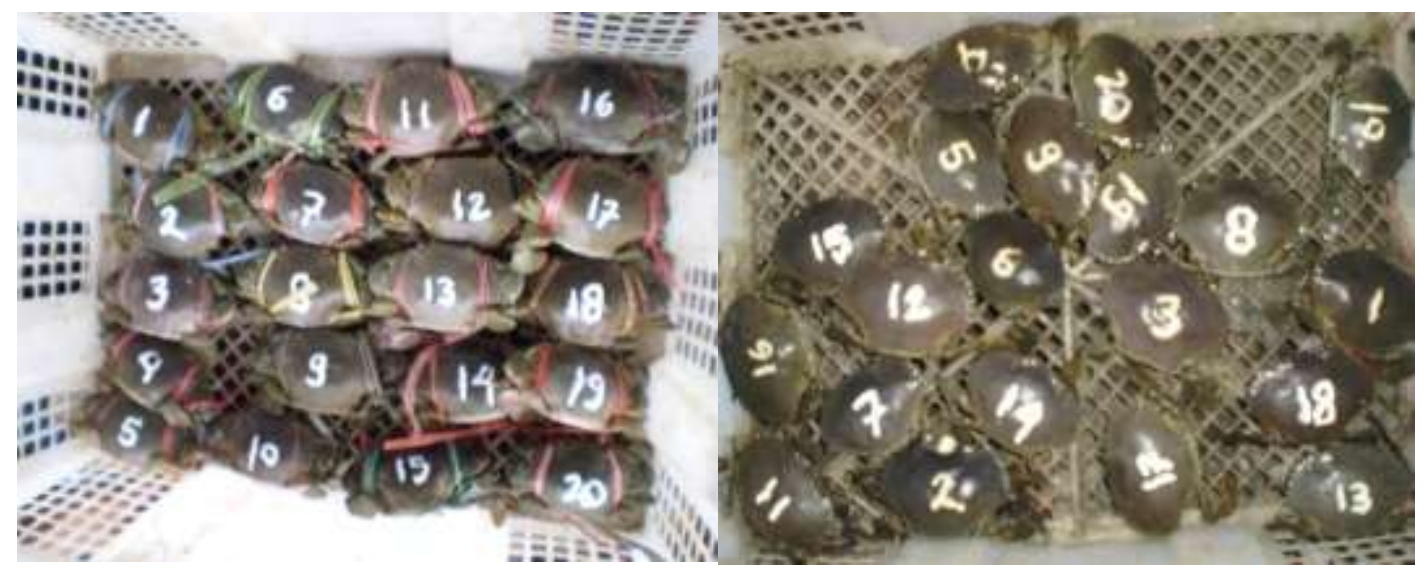

Lampiran 3. Hewan Uji yang Telah diberikan Perlakuan

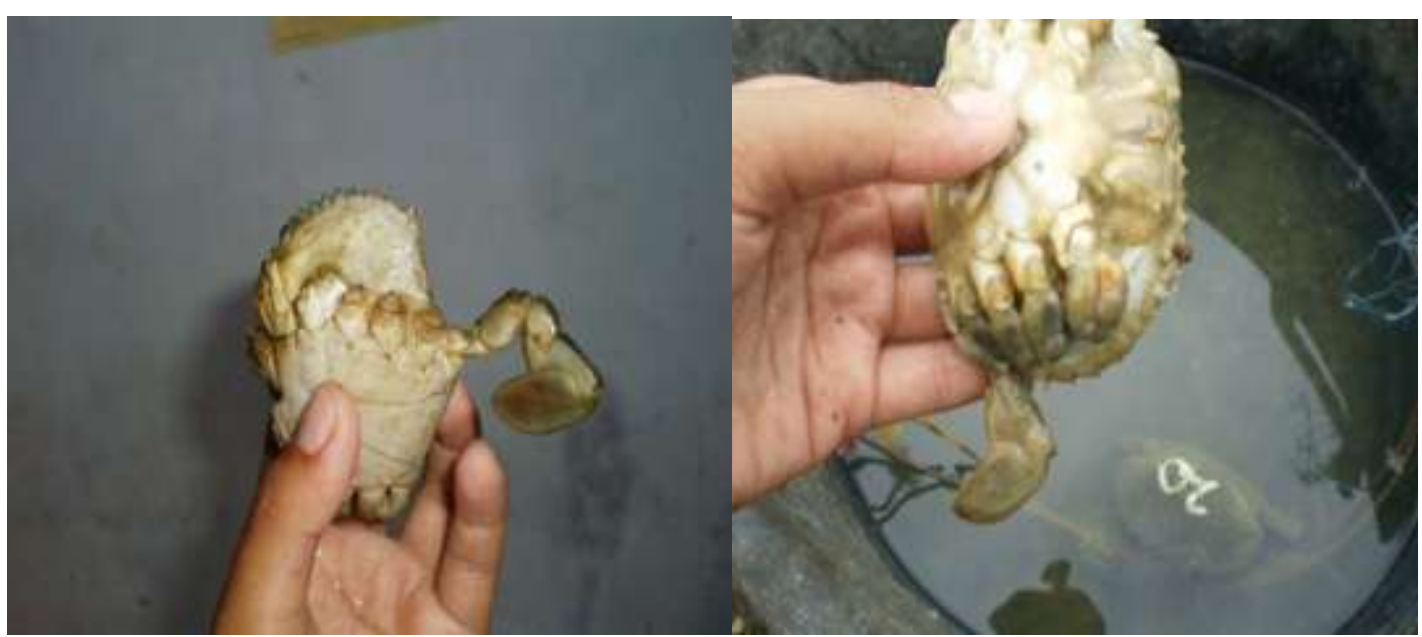

Lampiran 4. Perkembangan Organ Kaki Kepiting Mutilasi

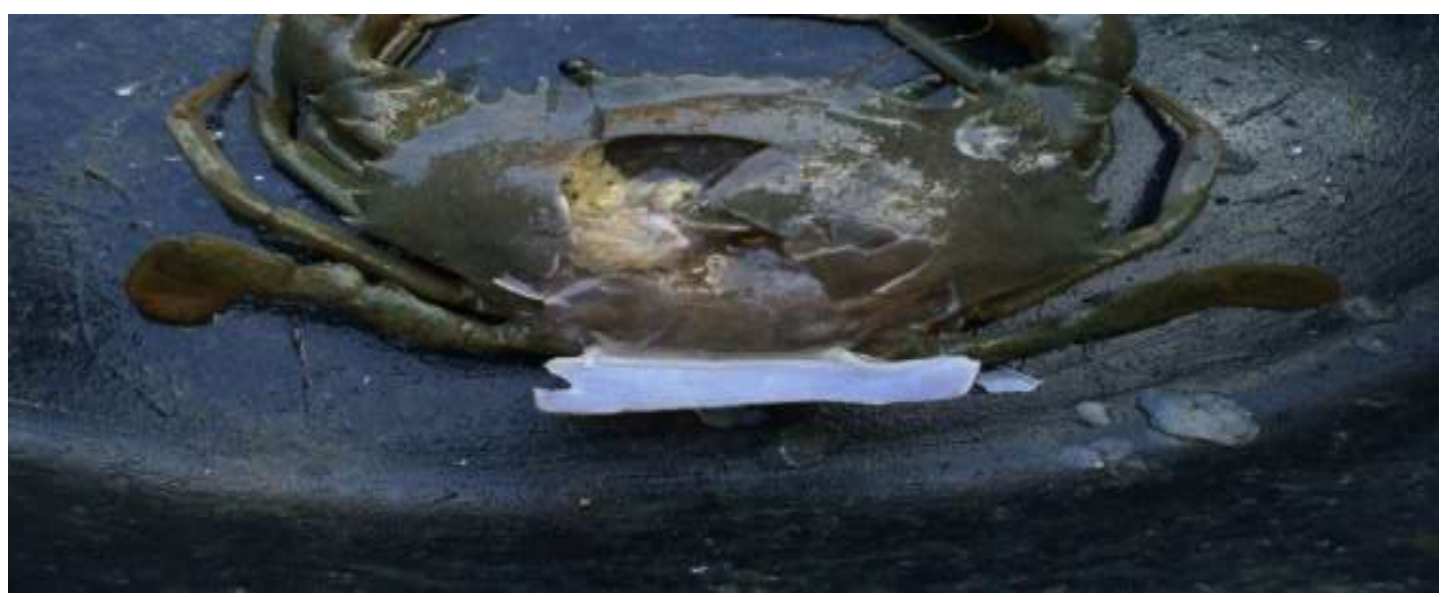

Lampiran 5. Kematian Karena Kanibalisme 


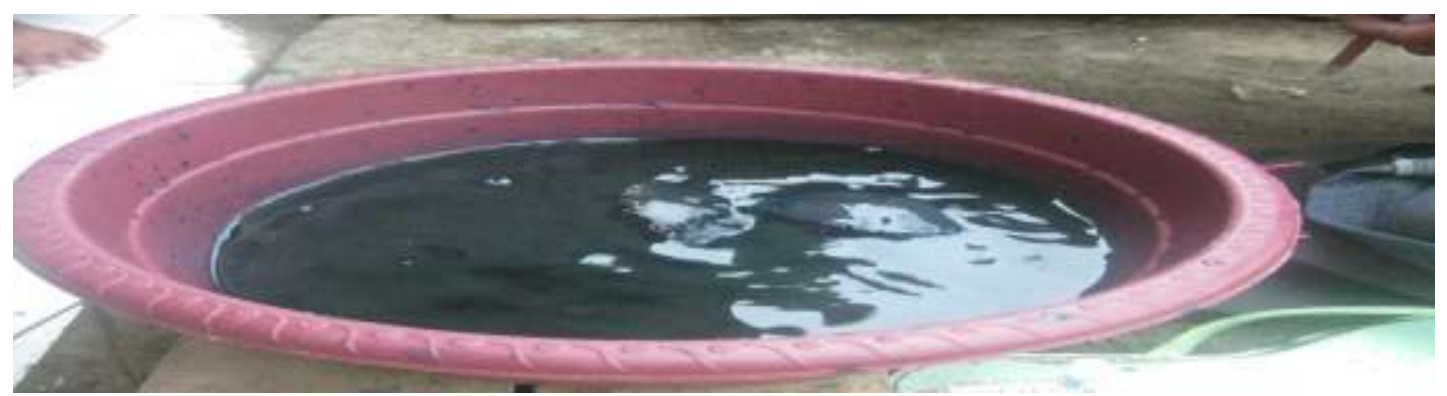

Lampiran 6. Perendaman dalam Metylend Blue

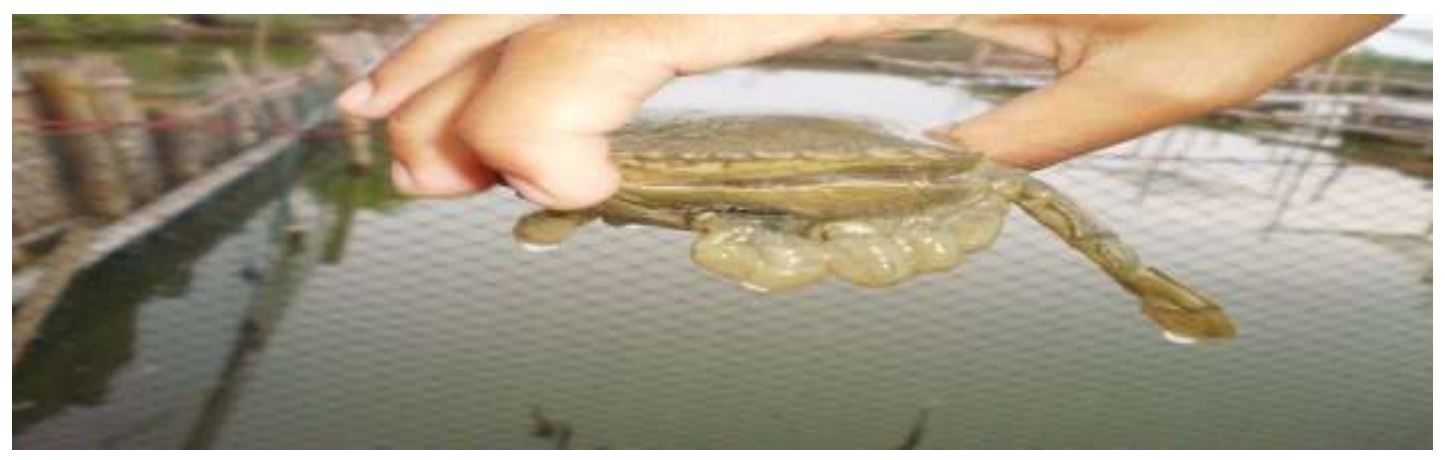

Lampiran 7. Selaput Tipis yang Lepas Bersama

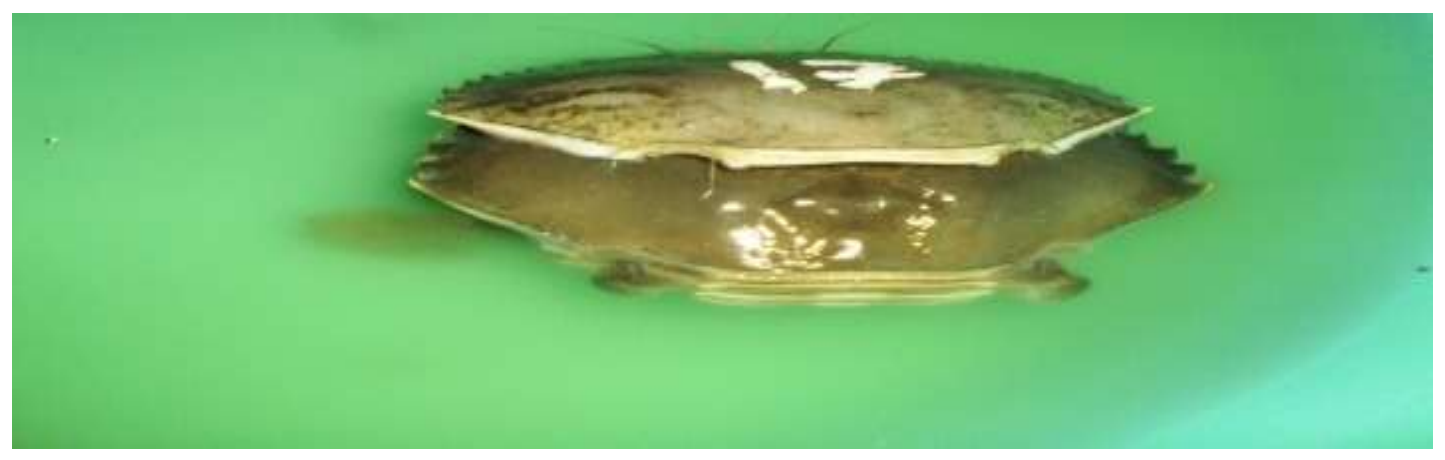

Lampiran 8. Kepiting yang sedang molting cangkang

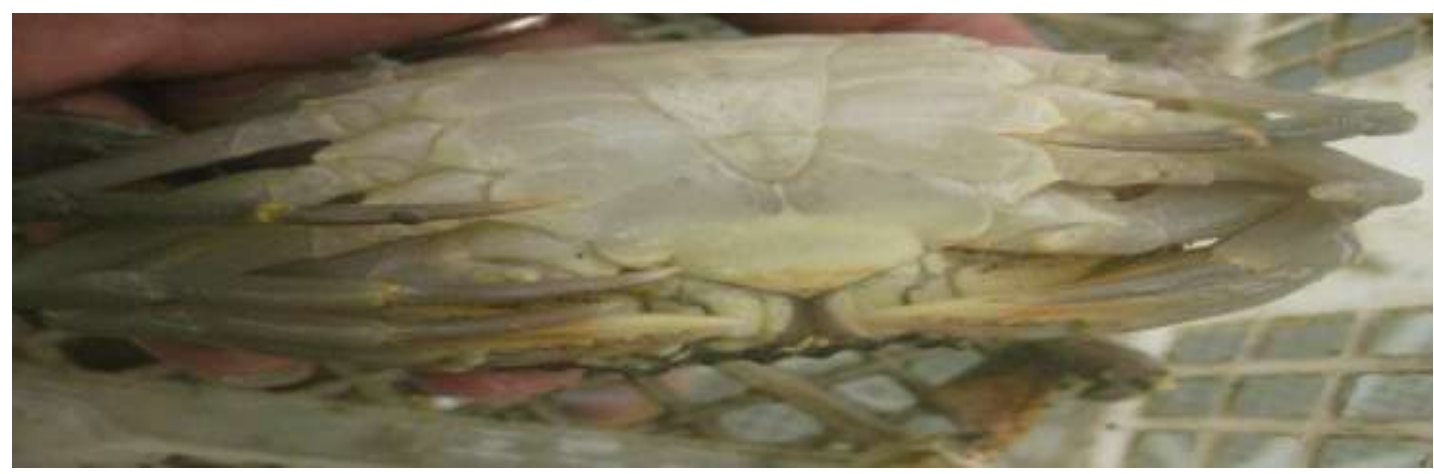

Lampiran 9. Kelengkapan organ kaki setelah molting 